\title{
Weekly Money Supply Forecasts: Effects of the October 1979 Change in Monetary Control Procedures
}

\author{
R. W. HAFER
}

T

HE activity of most financial market participants on Friday afternoons can be predicted with great accuracy: they anxiously will be awaiting the $4: 15 \mathrm{p} \cdot \mathrm{m}$. EST announcement of the new weekly money stock data. Despite the fact that the weekly data are contaminated by a great deal of "noise," a fact that greatly reduces the data's usefulness in revealing any policy trend, market participants still wager large sums and reputations on correctly anticipating the elusive weekly money figure. ${ }^{1}$

The impact of unanticipated changes in the weekly money supply on short-term interest rates has been investigated extensively. In general, the evidence shows a positive relationship between unanticipated changes in money and movements in market rates." Although this empirical relationship existed through-

\footnotetext{
${ }^{1}$ See David A. Pierce, "Trend and Noise in the Monetary Aggregates," in Federal Reserve Staff Study, New Monetary Control Procedures, vol. II (February 1981), especially pp. 19-22. Pierce estimates that the noise in weekly money data is around $\$ 3$ billion dollars, assuming an aggregate level of $\$ 400$ billion. As he notes, "In general, these results are further evidence that very little can be inferred from any but the most atypical movements in weekly data" (p. 22).

'See, for example, Jacob Grossman, "The 'Rationality' of Money Supply Expectations and the Short-Run Response of Interest Rates to Monetary Surprises," Journal of Money, Credit and Banking (November 1981), pp. 409-24, V, Vance Roley, "The Response of Short-Term Interest Rates to Weekly Money Announcements," Working Paper No. 82-06, Federal Reserve Bank of Kansas City (September 1982): Thomas Urich, "The Information Content of Weekly Money Supply Announcements," Joumal of Monetary Economics (July 1982), pp. 73-88; and Thomas J. Urich and Paul Wachtel, "Market Response to the Weekly Money Supply Announcements in the 1970s, Joumal of Finance (Decenber 1981), pp. 1063-72. For another interpretation: see Bradford Cornell, "Money Supply Amouncements and Interest Rates: Another View," Journal of Business (January 1983), pp. 1-23.
}

out the $1970 \mathrm{~s}$, the relative impact of weekly money "surprises" on short-term interest rates has been greater since the October 1979 change in monetary control procedures. In fact, over 25 percent of the volatility of the 3-month Treasury bill rate during the time period of the money supply announcement can be attributed directly to the increased volatility of unanticipated weekly changes in money since October $1979 .^{3}$ Moreover, unanticipated money supply changes that lie outside the Federal Reserve's announced money growth range appear to have a relatively greater effect on interest rates than money surprises falling within the announced growth range.

The evidence clearly indicates that unanticipated changes in the money stock have an important effect on interest rates. Consequently, examining the character istics of the money supply forecasts that give rise to such behavior is important. Several studies have examined the weekly money supply forecasts for the period prior to October 1979; but little has been done on comparing the forecasts across the announced change in monetary control procedures. ${ }^{5}$ The purpose of this article is to analyze the effects of the October

\footnotetext{
"Roley, "The Response of Short-Term Interest Rates."

"Ibid. See also, Neil G. Berkman, "On the Significance of Weekly Changes in M1," New England Economic Review (May-June 1978): pp. 5-22.

SStudies investigating the forecasts prior to the October 1979 policy shift are Grossman, "The 'Rationality' of Money Supply Expecta' tions," and Thomas Urich and Paul Wachtel, "The Structure of Expectations of the Weekly Money Supply Amouncement, "New York University, February 1982; processed). Roley, "The Response of Short-Term Interest Rates, provides some evidence on this issue for the period Febraary 1980 to November 1981.
} 
1979 change in monetary control on the weekly money supply forecasts. Under the assumption of rational expectations, a change from one recognized monetary control procedure to another should have no effect on the forecast characteristics. ${ }^{6}$ In other words, a change from one monetary control procedure to another should not affect the unbiased and efficiency aspects of the forecasts. If however, the new procedure is not "well-defined" - that is, the rules of the game are changing constantly - then weekly money supply forecasts may appear biased and inefficient. ${ }^{\top}$



The theory of rational expectations is based on the premise that market participants construct forecasts of the future in a manner that fully reflects the relevant information available to them. Because wealth-maximizing individuals will not make forecasts that are continually wrong in the same direction, the rational expectations approach suggests that forecasts of economic phenomena should be unbiased. Moreover, if the forecast errors could not have been reduced by using other available information, then forecasters have efficiently utilized the relevant data at their disposal.

The issue investigated here is whether the weekly forecasts of the Ml money stock change have been affected noticeably by the October 1979 change in monetary control procedures. More specifically, the question asked is: assuming rational expectations, has

\footnotetext{
The concept of rational expectations is based on the betief that econonic agents are utility maximizers. Thus, market participants form expectations that fully reflect all available information. More formally, rational expectations imply that individuals' subjective probability distribution of possible outcomes is identical to the objective probability distributions that actually occur. Conse. cuently, the only way policymakers can affect behavior is to "fool" the people in an inconsistent manner. This concept is developed more filly in John F. Muth, "Rational Expectations and the Theory of Erice Movements" Econometrica (July 1961) pp. 315-35. Robert E. Lucas, Jr. "Expectations and the Neutrality of Money," Journal of Economic Theory (April 1972), pp. 103-24; Robert $\mathrm{J}$. Barro, "Rational Expectations and the Role of Monetary Policy," Journal of Monetary Economics (January 1976), pp. 1-32; and Thomas J. Sargent and Neil Wallace, "Rational Expectations, the Optimal Monetary Irstrument, and the Optimal Money Supply Rule," Journal of Political Economy (April 1975), pp. 241-54.
}

"Implicit in this is the presumption that market participants will expend resources to decipher the new policy procedures and adapt their forecast formation process aceordingly. This does not seem unreasonable given the sophistication of financial market analysts in gauging actual Federal Reserve behavion. For a discussion on the transition from one policy to another and the implications for rational expectations, see Benjamin M. Friedman, "Optimal Expectations and the Extreme Information Assumptions of "Rational Expectations Macromodels," Joumal of Monetary Economics Jantary 1979), pp. 23-41. the change in monetary control procedures affected the unbiased and efficiency characteristics of the weekly money supply forecasts? If the forecasts from the post-October 1979 period are not different than those from before, we then would conclude that the forecasters have adapted to the new policy regime. If they differ, however, the evidence would not reject the hypothesis that they have been tunable to ascertain the policymaker's behavioral rule. ${ }^{8}$

Three sample periods are used in the following analysis. The full period is from the week ending January 11,1978 , to the week ending June 16, 1982. Given the change in operating procedures in late 1979 , the relevant subperiods are from the week ending January 11 , 1978 , to the week ending October 3, 1979, and from the week ending October 10,1979, to the week ending June $16,1982 .{ }^{9}$ With these sample periods, the unbiased and efficiency characteristics of the weekly money supply forecasts across the change in monetary control procedures can be investigated.

\section{Weakly Money Srmply Data}

The money data series used in this article are the actual and expected, initially announced week-to-

\footnotetext{
"The dilemma facing market participants is known as the "Lucas problem." Essentially, even though individuals act rationally in making their forecasts - that is, use all of the information thought to be relevant - failure to account for a procedural shift will lead to incorrect forecasts. Thus, forecasting guidelines used under one procedure may not apply under another. For the specific problem tested here, it may be the case that the announced policy differs from that actually followed. If policy actions ate not characterized easily, that is, if policy is unpredictable, then forecasts may be biased and inefficient simply because agents have not determined the structure of the model. For a discussion of this concept, see Robert F. Lucas, Jr., "Econometric Policy Evaluation: A Critique," in Karl Brunner and Allan H. Meltzer, eds., The Phillips Curve and Labor Markets, The Carnegie-Rochester Conference Series on Public Policy (vol. 1, 1976), pp. 19-46.
}

Bradford Comell recently has argued that apparent irrational behavion on the part of market participants evidenced by biased and inefficient forecasts, may very well be due to the change from a predictable policy regime to one that continues to be umpredictable. As he states, On October 6 [1979], market participants suddenly discovered that even the rules of the game were subject to change. As a result, they began studying weekly money supply figures not only with the goal of determining what the current policy was, but also with the goal of determining how the rules of the game might be changed. "In this sense, market participants face a perpetial "Licas problem." See Cornell, "Money Supply Announcements and Interest Rates: Another View, " p. 21.

Note that the post-October 1979 period includes the period of credit controls, essentially the second quarter of 1980 . This period is included becaise an examination of the error pattern from weekly money forecasts indicated no difference between this period and any other. Moreover, market participants contimued to forecast weekly money changes throughout the control period. 
week changes in the narrowly defined money stock (M1). Figures for the actual changes in M1 are taken from the Federal Reserve's H.6 weekly statistical release. Because the sample covers a period of changing definitions, the following guideline is used: From January 11, 1978, to January 31, 1980, the weekly money supply changes are based on the old definition of M1. From February 8, 1980, to November 20, 1981, the money stock is defined as the actual M1B measure, not the M1B figure that was adjusted for NOW account movements. Finally, from November 27,1981 , to June 16,1982 , the data are based on the then-current definition of $\mathrm{Ml}$.

The data used as a measure of the market's forecasts were obtained from Money Market Services, Inc. ${ }^{10}$ Since 1977 this firm has conducted a weekly telephone survey of 50 to 60 government securities dealers to get their expectations of the impending change in money, Prior to early 1980, the poll was conducted twice a week, on Tuesdays and Thursdays. Since then, however, only the Thursday survey has been conducted consistently, because of the shift in the Federal Reserve's announcement of the weekly money supply figures from Thursday to Friday afternoon. For our purposes, therefore, we employ the mean of the Thursday survey responses. ${ }^{11}$

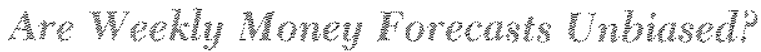

Forecasts of weekly changes in the money stock are unbiased predictors of the actual change if the actual and forecasted values differ only by some random term. Mathematically, this requirement can be stated 25

(1) $\Delta \mathrm{M}_{\mathrm{t}}={ }_{\mathrm{t}-1} \Delta \mathrm{M}_{\mathrm{t}}^{\mathrm{E}}+\varepsilon_{\mathrm{t}}$

where $\Delta \mathrm{M}_{\mathrm{t}}$ is the actual change in the money stock, ${ }_{t-1} \Delta \mathrm{M}_{\mathrm{t}}^{\mathrm{E}}$ is the expectation held in period $t-1$ for the change in the money stock in period $t$, and $\varepsilon_{t}$ is a random error term with zero mean and variance $\sigma_{\varepsilon}^{2}$.

\footnotetext{
101 has been argued that survey data are not good measures of the market's expectations of some macroeconomic variable. This argument is founded on the belief that most survey respondents are not actual market participants. In other words, their responses to the survey are not based on some profit-maximizing behavior that has generated the forecast. The weekly money forecasts used here are taken from dealers actively participating in the financial market, thus reducing the force of this criticism. See Edward J. Kane and Burton G. Malkiel "Autoregressive and Nonautoregressive Elements in Cross-Section Forecasts of Inffation, "Fconometrica (January 1976), pp. 1-16.

${ }^{12}$ For an analysis of the Tuesday and Thursday forecasts, see Grossman, "The "Rationality" of Money Supply Expectations." This analysis covers only the period 1977 to 1979 .
}

To test for the absence of bias, equation 1 is rewritten and estimated as

(2) $\Delta \mathrm{M}_{\mathrm{t}}=\alpha_{0}+\beta_{\mathrm{I}-\mathrm{l}} \Delta \mathrm{M}_{\mathrm{t}}^{\mathrm{E}}+\varepsilon_{\mathrm{t}}$

where $\alpha_{0}$ and $\beta_{1}$ are the parameters to be estimated. ${ }^{12}$ In this form, the weekly money forecasts are unbiased predictors of actual money supply changes if the joint hypothesis that $\hat{\alpha}_{0}=0$ and $\hat{\beta}_{1}=1$ camnot be rejected. Moreover, the estimated residuals from this regression $\left(\hat{\boldsymbol{\varepsilon}}_{t}\right)$ should not exhibit serial correlation if the forecasts are unbiased predictions of the actual change in money,

Table 1 presents the regression results from estimating equation 2 using the expected and actual money stock changes. The full-period results suggest that the forecasts of weekly changes in the money stock are unbiased predictors of the actual changes. The calculated $F_{\text {-statistic does not exceed the critical value of }}$ 3.04 at the 5 percent significance level. Consequently, the null joint hypothesis that $\hat{\alpha}_{0}=0$ and $\hat{\beta}_{1}=1$ is not rejected. Moreover, the residuals of the equation show no indication of first-order serial correlation, as evidenced by the Durbin-Watson statistic. Thus, the weekly money supply forecasts appear to be unbiased across the full sample.

To see if the forecasts are unbiased before and after the October 1979 change in monetary control procedures, equation 2 was re-estimated for the two periods January 11,1978 , to October 3,1979 , and October 10 , 1979 , to June 16,1982 . These regression results also are reported in table $1 .{ }^{13}$

The estimates from the pre-October 1979 period again indicate that the forecasts are unbiased. The calculated $\mathbf{F}$-statistic is not statistically significant, and the Durbin-Watson statistic again indicates no firstorder serial correlation among the residuals. In contrast, the post-October 1979 regression results permit us to reject the hypothesis that the forecasts are unbiased predictors of the actual changes. Although the estimated constant term is statistically insignificant, the hypothesis that the estimated slope term $\left(\hat{\beta}_{1}\right)$ does not differ from unity is rejected easily $(t=2.33)$. Consequently, the joint hypothesis underlying this

\footnotetext{
${ }^{k 2}$ This type of test is used widely in studies of expectations data. For studies examining money stock forecasts, see, for example, Grossman, "The "Rationality" of Money Supply Expectations;" Urich and Wachtell, "The Structure of Expectations;" and Roley, "The Response of Short-Term Interest Rates."

${ }^{1.3}$ This dichotomization of the sample is supported statistically by Chow-test results: the calculated $F$-value is $\mathbf{F}(2,228)=3.93$, which exceeds the critical 5 percent level.
} 


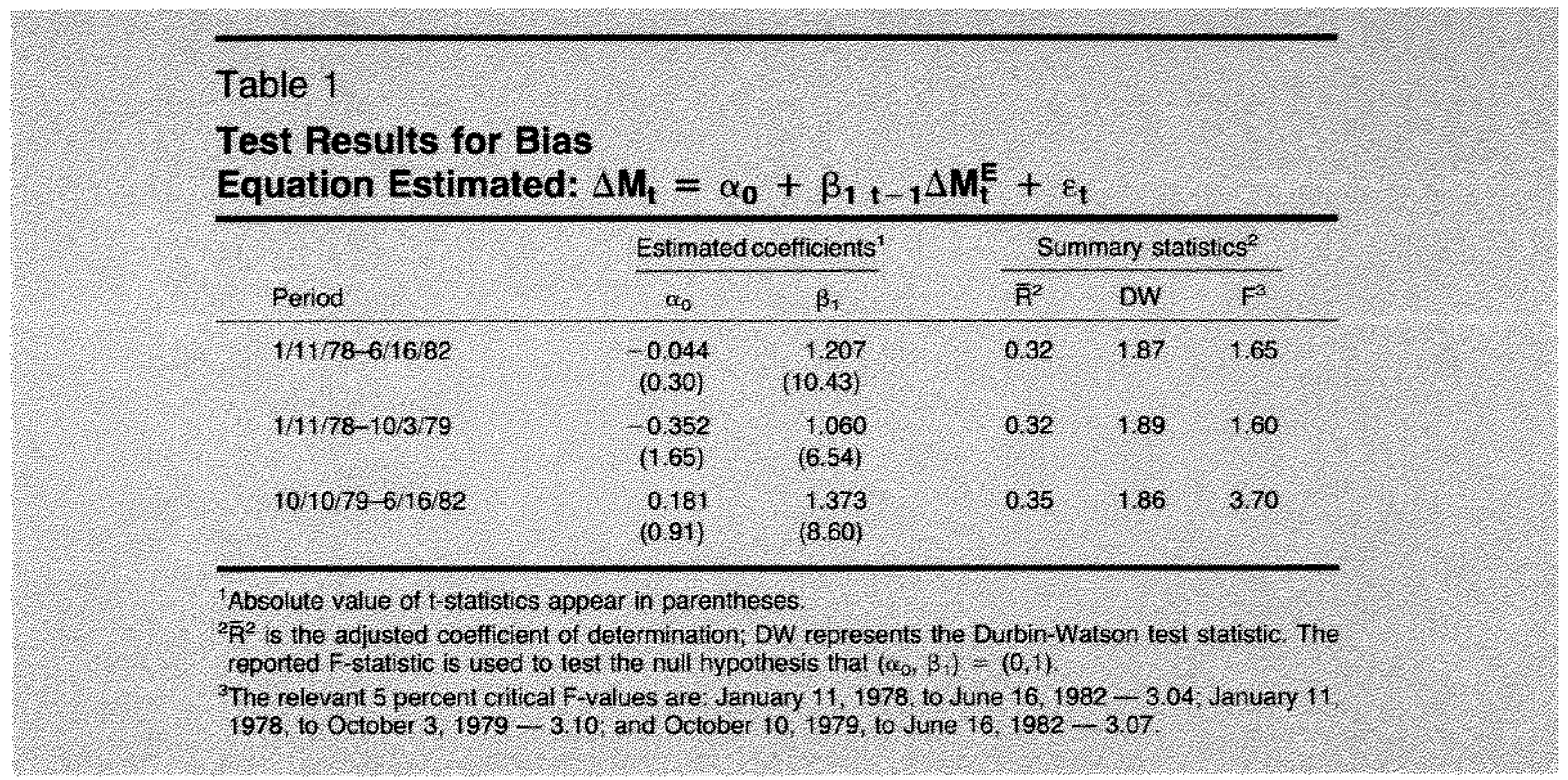

test also is rejected; the calculated $\mathrm{F}$-statistic of 3.70 exceeds the 5 percent critical value of 3.07 . Thus, the evidence suggests that forecasts of weekly money supply changes have been biased since the October 1979 change in implementing monetary policy.

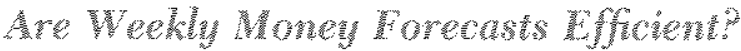

The efficiency condition requires that forecasts fully reflect all pertinent and readily available information. ${ }^{14}$ Since the information available to individuals includes the past history of the series being forecast, it is possible to test the hypothesis that the forecasts are "weakly" efficient; that is, at least the information con" tained in the history of weekly money supply changes is used efficiently. This concept of efficiency requires that the process actually generating observed changes in weekly money and the process generating the forecasts of these changes are the same. The simplest process to assume is an autoregressive one, where observed and expected changes are generated solely by the past history of the series itself. Mathematically, this concept of efficiency can be stated as

(3) $\Delta \mathrm{M}_{t}=\sum_{i=1}^{\mathrm{n}} \boldsymbol{\beta}_{i} \Delta \mathrm{M}_{\mathrm{t}-\mathrm{i}}+\mu_{\mathrm{k} t}$,

${ }^{14}$ of course, additional information will be acquired only if the marginal benefits are at least as large as the marginal costs of acquisition. $A$ useful discussion of this point is provided in Armen A. Alehian, "Information Costs, Pricing, and Resolurce Unemployment," in Edmand S. Phelps, and others, Microeconomic Foundations of Employment and Infation Theory (W. W. Norton \& Company, Ine., 1970), pp. 27-52
(4) $t-1 M_{t}^{E}=\sum_{i=1}^{n} \beta_{i}^{t} \Delta M_{t-i}+\mu_{2 t}$

where $\mu_{1 \mathrm{t}}$ and $\mu_{2 \mathrm{t}}$ are random error terms. In this format, weak-form efficiency requires that $\beta_{i}=\beta_{i}^{\prime}$ for all $\mathbf{i} ; \mathbf{i}=1,2, \ldots$, n. $^{15}$

To determine if survey respondents efficiently utilized the information contained in past weekly money supply changes, equation 4 is subtracted from equation 3 , yielding the estimated equation

$$
\Delta M_{t}-i-1 \Delta M_{t}^{E}=b_{9}+\sum_{i=1}^{n} b_{i} \Delta M_{t-i}+\phi_{t}
$$

where the dependent variable $\Delta \mathrm{M}_{\mathrm{t}}-{ }_{\mathrm{t}-1} \Delta \mathrm{M}_{\mathrm{t}}^{\mathrm{E}}$ represents the forecasters' errors in predicting weekly money changes, and the independent variables, $\Delta \mathrm{M}_{\mathrm{t}-\mathrm{i}}$, are the actual changes in money. ${ }^{16}$ The equation permits a constant term $\left(b_{0}\right)$ to be estimated instead of subsuming it into the error structure, which is represented by the term $\phi_{\mathrm{t}}\left(=\mu_{1 t}-\mu_{2 t}\right)$. The null hypothesis to be tested is that the estimated $b_{i}\left(=\beta_{i}-\right.$

\footnotetext{
${ }^{15}$ This form of the efficiency test was proposed in James E. Pesando, "A Note on the Rationality of the Livingston Price Expectations Data, Joumal of Political Economy (August 1975), pp. 849-58.

${ }^{16}$ The lagred values of data used in the efficiency test are the one-week revised numbers, not the initially reported weekly figures. Since the revised figures contain more information than the originaly released tata - the data contained in the revision itself - using original data would deprive forecasters of some information. It should be noted, however, that the conclusions reached were not affected when originally reported data was used to generate lagged changes in the money stock.
} 


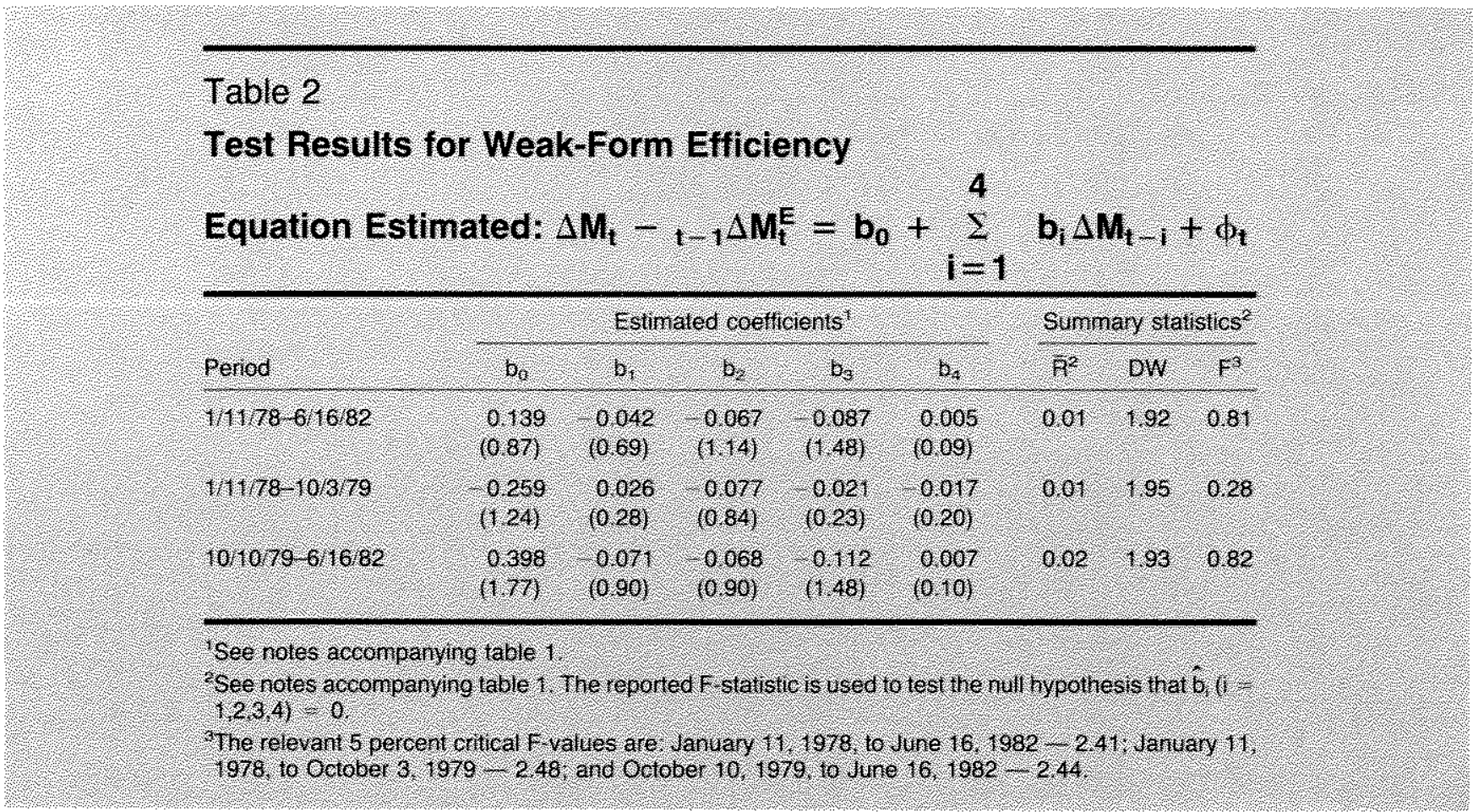

$\left.\beta_{i}^{\prime}\right)$ are not statistically different from zero for all $\mathrm{i}(\mathrm{i}=$ $1,2, \ldots, n$ ) as a group. Moreover, the estimated error structure should not exhibit serial correlation. ${ }^{17}$

Table 2 presents the results of estimating equation 5 for the period January 11, 1978, to June 16, 1982. Four lags were chosen to capture the informational content of past changes in weekly money. The regression results indicate that past changes in the money supply do not explain any significant portion of the forecast error. The calculated F-statistic (0.81) is far below acceptable critical values. The Durbin-Watson statistic also indicates that serial correlation is not present among the residuals. Thus, for the full period, we cannot reject the hypothesis that forecasters efficiently used the information contained in past changes in the money stock in forming their predictions.

We next test the efficiency hypothesis for the preand post-October 1979 periods; these empirical results also are found in table 2 . In both instances, we again cannot reject the hypothesis that past information about weekly money changes was used efficiently. Neither F-statistic is significant at the 5 percent level. Based on these results, therefore, the weak $\mathrm{f}$ form efficiency hypothesis is not rejected by the data, regardless of the sample used.

\footnotetext{
${ }^{17}$ See Donald I. Mullineaux, "On Testing for Rationality: Another Look at the Livingston Price Expectations Data," Journal of Polit ical Economy (April 1978), pp. 329-36 for a discussion of this test.
}

\section{Tests of Stronger-iom Effichon}

The above evidence suggests that forecasts of weekly money stock changes are weakly efficient. Efficiency, however, also may be considered in a broader sense. This broader efficiency criterion requires that forecasts incorporate all of the relevant and available information. Thus, similar to the previous hypothesis, efficiency in the broad sense requires that the forecast errors be orthogonal, or systematically unrelated to all relew vant available information sets. ${ }^{18}$

To test this concept of efficiency, we estimate the equation

(6) $\Delta \mathrm{M}_{\mathrm{t}}-\mathrm{e}_{\mathrm{t}-1} \Delta \mathrm{M}_{\mathrm{t}}^{\mathrm{E}}=\mathrm{c}_{0}+\sum_{\mathrm{i}=0}^{\mathrm{n}} \mathrm{c}_{\mathrm{i}} \mathrm{I}_{\mathrm{t}-\mathrm{i}}+\mathrm{w}_{\mathrm{t}}$,

where $I_{t-i}$ refers to lagged values $(i=0,1, \ldots, n)$ of information that are not incorporated in past money stock changes, and $w_{\mathrm{t}}$ is another random error term. The analysis is intended to determine whether the survey respondent's weekly errors in forecasting money supply changes can be explained by some set(s) of information that are readily available. If the esti-

\footnotetext{
${ }^{18}$ Tests using this stronger form of efficiency are presented in Grossman, "The 'Rationality' of Money Supply Expectations," and using interest rate expectations data, in Benjamin M. Friedman, "Survey Evidence on the 'Rationality" of Interest Rate Expectations, "Journal of Monetary Economics (October 1980), pp. 45365. where the phrase "information orthogonality" was coined
} 


\section{Table 3}

\section{Test Results for Stronger-Form Efficiency}

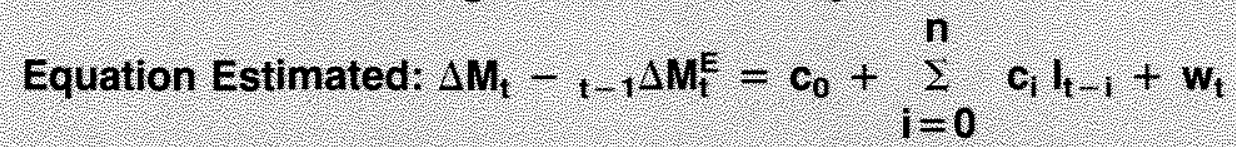

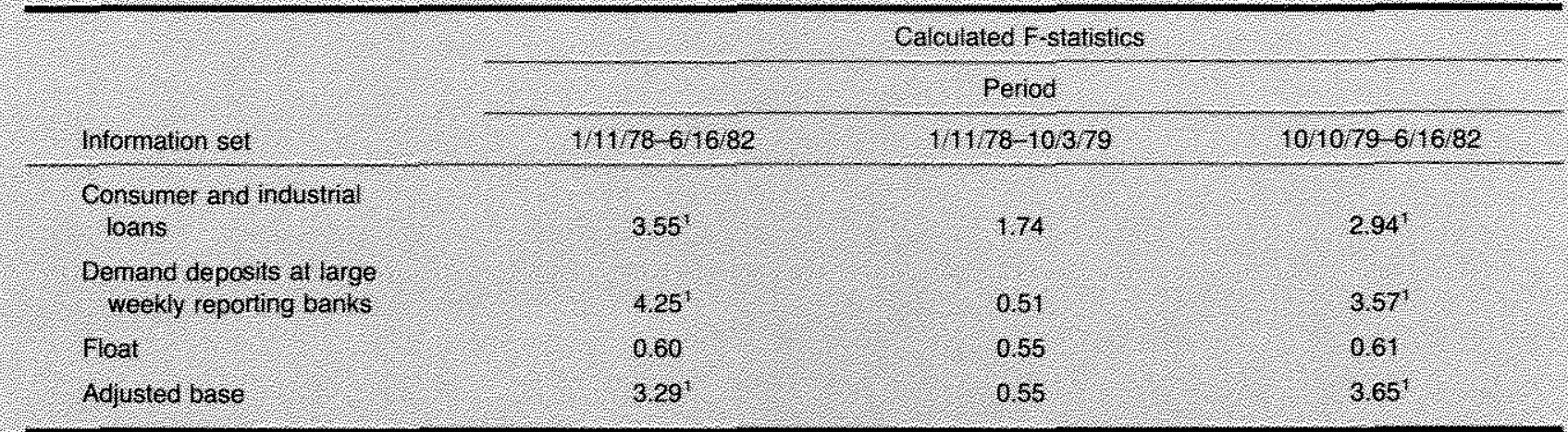

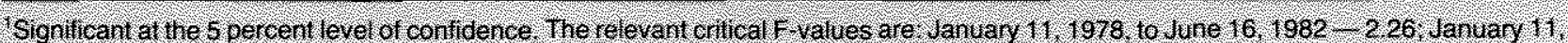
1976. 10 October 3,1979 - 232 and Oclober 10,1979 , to June 16,1982 , 228

mated $c_{i}$ coefficients are not significantly different from zero as a group, then we camnot reject the strongerform hypothesis of efficiency. If contrary evidence is found, then the results would suggest that forecasters could have reduced their prediction errors by using the information sets investigated here.

It is, of course, impossible to account for every imag. inable information set that each forecaster could have used. Consequently, we analyze several sets of information that are available on a timely basis and are potentially useful in estimating future money stock developments. The information sets used are consumer and industrial loans, demand deposits at large weekly reporting banks, float and the adjusted monetary base as defined by the Federal Reserve Bank of St. Louis. In all cases, the data used are taken from original Federal Reserve statistical releases that were available to forecasters prior to the weekly money stock announcements. ${ }^{19}$ Although we realize that the series

\footnotetext{
${ }^{19}$ All data are in terms of level changes from the previous week. Data sources are the Federal Reserve $\mathrm{H} 4.1$ and $\mathrm{H} 4.2$ statistical releases, and the Federal Reserve Bank of St. Louis.

This procedure mav impart some measurement error since only the initially released data are used. Given the short time horizon used and the observation that the weekly data revisions are not severe, the approach used seems sufficient. It also should be noted that, since February 1980 , datta on consunier and industrial loans and demand deposits at weekly reporting banks have been released concurrently with the money supply numbers. Thus, these two series offer no prior information during the post-
}

chosen do not exhaust the set of possible information sources, they are sufficiently broad to test the hypothesis at hand.

Table 3 reports the calculated F-statistics from estimating equation 6 using the different information sets. In each test, the information set contains contemporaneous and four lagged terms. The outcome for the full period suggests that forecasters efficiently utilized the information contained in the float information set: the reported $\mathrm{F}$-statistic is not large enough to reject the null hypothesis. The results for the other information sets - consumer and industrial loans, demand deposits at large weekly reporting banks and the adjusted base - reject the efficiency hypothesis. For these, the F-statistics exceed the 5 percent critical value $(2.26)$, implying that forecast errors could have been lessened if the information contained in these data had been used.

Equation 6 was re-estimated for the pre.. and postOctober 1979 periods; these results also are found in table 3 . The full-period results are dominated by the post-October 1979 period. Prior to the shift in control procedures, forecasters' predictions of weekly money supply changes appear to have efficiently incorporated the information sets tested here: all the $F$-statistics are less than the 5 percent critical value (2.32). In contrast,

February 1980 period. They do, however, provitle more information that forecasters may use in generating their expected money numbers. 
the post-October 1979 results reveal that, except for float, the forecasters could have improved upon their ability to predict changes in the money stock by incorporating the information contained in the series on loans, demand deposits and the adjusted base. Thus, over the recent period, the forecasts do not meet the broader efficiency criterion tested here.

\section{CONCISTON}

Previous examinations of survey data on weekly money supply forecasts have focused primarily on the effects of unanticipated money changes on market interest rates. Although several studies have examined the forecasts' rationality, there has been no systematic investigation into the effect of the change in monetary control procedures on the unbiased and efficiency characteristics of the forecasts.
The evidence presented here indicates that the change in control procedures has had a significant effect on the characteristics of weekly money supply forecasts. Prior to October 1979, the forecasts of the change in the weekly money stock were unbiased and efficient. In contrast, weekly money forecasts since October 1979 have been biased and inefficient.

The results of this investigation lend support to the recently suggested hypothesis that, since October 1979, "market participants [have] concluded that the rules under which monetary policy is conducted could no longer be considered constant. "20 If this indeed is true, then the combined evidence from this study and those dealing with the interest rate effects of unanticipated money supply changes suggests that a more predictable control procedure would contribute to a more stable financial market.

\footnotetext{
${ }^{20}$ Cornell, "Money Supply Announcements," p. 22.
} 